\title{
Root Distribution of Plantains Growing on Five Soil Types ${ }^{1,2}$
}

\begin{abstract}
Héber Irizarry, José Vicente-Chandler, and Servando Silva ${ }^{3}$ ABSTRACT

Plantain roots decreased sharply with depth and distance from the pseudostem on 5 soils typical of vast areas in the tropics. Primary roots in the upper $15 \mathrm{~cm}$ of all soils decreased from an average of $111 \mathrm{~cm} / 1,000 \mathrm{~cm}^{3}$ of soil at $0-30 \mathrm{~cm}$ from the pseudostem, to $29 \mathrm{~cm} / 1,000 \mathrm{~cm}^{3}$ of soil at $60-90 \mathrm{~cm}$ from the pseudostem. At $0-30 \mathrm{~cm}$ from the pseudostem, roots decreased from $111 \mathrm{~cm} / 1,000 \mathrm{~cm}^{3}$ of soil in the upper $15 \mathrm{~cm}$ of soil to $11 \mathrm{~cm} / 1,000$ $\mathrm{cm}^{3}$ of soil at the $30-45 \mathrm{~cm}$ depth. No roots were present below $45 \mathrm{~cm}$ in any soil.
\end{abstract}

\section{INTRODUCTION}

Information on the distribution of plantain roots in different soil types is important as a basis for developing effective cultural practices such as irrigation and fertilization. The root system of bananas (Musa acuminata, AAA) has been studied by Sumerville ${ }^{4}$, but we found no reference to such studies with plantains (Musa acuminata $\times$ M. balbisiana, AAB).

This paper describes the distribution of plantain primary roots in five different soil types typical of large areas in the humid tropics.

\section{MATERIALS AND METHODS}

Following is a brief description of the sites and soils where the studies were conducted.

\section{Corozal clay at Corozal}

This site is located at an elevation of about $200 \mathrm{~m}$ and receives an annual rainfall of about $1,650 \mathrm{~mm}$. Average annual temperature is about $25^{\circ} \mathrm{C}$ with mean monthly variations of about $5^{\circ} \mathrm{C}$.

The Corozal (Ultisols) is a clayey, mixed isohyperthermic Aquic Tropudults, derived from early tertiary volcanic conglomerates. The surface soil is well drained but the subsoil is only moderately so. The surface soil $(0-30 \mathrm{~cm})$ is clayey with a fine, subangular, very strong blocky structure. The subsoil has brown streaks, and thick continuous clay films cover the aggregates. The predominant clay minerals are kaolinite and vermiculite.

${ }^{1}$ Manuscript submitted to Editorial Board July 9, 1979.

${ }^{2}$ This paper covers work carried out cooperatively between Agricultural Research, Science and Education Administration, USDA and the Agricultural Experiment Station, Mayagüez Campus, University of Puerto Rico.

${ }^{3}$ Horticulturist, Soil Scientist and Research Technician, Science and Education Administration, USDA, Río Piedras, PR, respectively.

${ }^{4}$ Sumerville, W. A. T., 1939. Root Distribution of the bananas, Queens. Agri. J. (52):37692. 
The Corozal clay is on a $15 \%$ slope, has $3 \%$ organic matter and a pH of 5.3. Cation exchange capacity is $16 \mathrm{me} / 100 \mathrm{~g}$ of soil and exchangeable bases are $11 \mathrm{me} / 100 \mathrm{~g}$ of soil. Bulk density is $1.2 \mathrm{~g} / \mathrm{cm}^{3}$ in the surface 15 $\mathrm{cm}$ and $1.3 \mathrm{~g} / \mathrm{cm}^{3}$ at all other depths. This soil has a moisture content of $45 \%$ at field capacity.

\section{Coloso clay at Gurabo}

This site is adjacent to that described below for Mabi and has the same climatic characteristics.

The Coloso (Entisols) is a fine, mixed, nonacid, isohyperthermic Aeric Tropic Fluvaquents. The surface soil is dark-brown, silty clay. It is firm, slightly sticky and slightly plastic. The subsoil is firm, and more plastic and sticky than the surface soil. It forms dense clods when plowed. This soil is derived from moderately fine textured sediments from surrounding hills. The predominant clay mineral is kaolinite with some 2:1 clays.

The soil is on a $2 \%$ slope, has $4 \%$ organic matter and a $\mathrm{pH}$ of 6.0 . Cation exchange capacity is $28 \mathrm{me} / 100 \mathrm{~g}$ of soil and exchangeable bases are 26 me/100 g of soil. Bulk density is $1.2 \mathrm{~g} / \mathrm{cm}^{3}$ in the surface soil and $1.3 \mathrm{~g} /$ $\mathrm{cm}^{3}$ in the subsoil. At field capacity this soil has a moisture content of $34 \%$.

\section{Cayaguá soil at San Lorenzo}

This site is located at an elevation of about $200 \mathrm{~m}$. Annual rainfall is about $2,000 \mathrm{~mm}$, and temperatures are similar to those at Corozal.

Cayaguá (Inceptisols) is a fine, mixed, isohyperthermic Aeric Tropaqualfs derived from quartz diorite. It has a moderately permeable surface layer but restricted internal drainage. The surface $(0-30 \mathrm{~cm})$ is sandy loam, fine granular, and nonsticky. The subsoil is brownish-gray clay with brown mottling. It is very firm when moist and somewhat sticky and plastic when wet. The predominant clay mineral is kaolinite.

The Cayagua soil is on a $30 \%$ slope, has $4.5 \%$ organic matter and a pH of 6.0. Cation exchange capacity is $10 \mathrm{me} / 100 \mathrm{~g}$ soil and exchangeable bases are $8 \mathrm{me} / 100 \mathrm{~g}$ of soil. Bulk density is $1.4 \mathrm{~g} / \mathrm{cm}^{3}$ in the surface layer and $1.3 \mathrm{~g} / \mathrm{cm}^{3}$ in the subsoil. This soil has a moisture content of $31 \%$ at field capacity.

\section{Humatas clay at Aguas Buenas}

This site, located at an elevation of about $400 \mathrm{~m}$, receives about 1,800 $\mathrm{mm}$ annual rainfall. Average annual temperature is about $24^{\circ} \mathrm{C}$ with mean monthly variations of about $5^{\circ} \mathrm{C}$.

Humatas (Ultisol) is a clayey, mixed, isohyperthermic Typic Tropohumults, derived from volcanic rocks, mainly andesitic tuffs. The surface soil has a fine to medium subangular blocky structure and is slightly 
plastic when wet. The subsoil $(35 \mathrm{~cm}$ ) has a weak fine subangular blocky structure and is slightly plastic. The predominant clay mineral is kaolinite.

The Humatas clay is on a $25 \%$ slope, has $3.5 \%$ organic matter and a $\mathrm{pH}$ of 5.5. Cation exchange capacity is $13 \mathrm{me} / 100 \mathrm{~g}$ of soil and exchangeable bases are $10 \mathrm{me} / 100 \mathrm{~g}$ of soil. Bulk density of the soil ranges from $1.0 \mathrm{in}$ the surface layer to $1.1 \mathrm{~g} / \mathrm{cm}^{3}$ at the $30-45 \mathrm{~cm}$ depth. At field capacity this soil contains $42 \%$ moisture.

\section{Mabí soil at Gurabo}

This location is at an elevation of about $80 \mathrm{~m}$. Annual rainfall is 1,500 $\mathrm{mm}$, and there is a well-defined winter dry season. Average annual temperature is $26^{\circ} \mathrm{C}$ with monthly variations of about $5^{\circ} \mathrm{C}$.

Mabí (Inceptisols) is a montmorillonitic isohyperthermic Vertic Eutropepts. It is rather poorly drained and has slow permeability. The surface soil is a dark-grayish-brown clay with yellow, brown and red mottles. It has a fine granular structure. The subsoil is yellowish brown with many distinct gray mottles. It has a weak, fine, angular, blocky structure and is very firm and plastic when wet. Clay minerals are predominantly montmorillonite with moderate amounts of kaolinite and small quantities of mica.

The Mabí soil is on about a $4 \%$ slope, has $4 \%$ organic matter and a $\mathrm{pH}$ of 6.0. Cation exchange capacity is $24 \mathrm{me} / 100 \mathrm{~g}$ of soil and exchangeable bases are $21 \mathrm{me} / 100 \mathrm{~g}$ of soil. Bulk density is $1.5 \mathrm{~g} / \mathrm{cm}^{3}$ in the surface soil and $1.6 \mathrm{~g} / \mathrm{cm}^{3}$ at lower depths. At field capacity the soil has a moisture content of $40 \%$.

The plantain fields at all locations were at least 2 ha and were planted to a high-yielding clone of the Maricongo cultivar. The soil was limed to about $\mathrm{pH} 5.5$ where necessary and the soil at all sites was plowed several times before planting. Plant spacing was $1.8 \times 1.8 \mathrm{~m}$, which is equivalent to about 3,100 plants/ha, and close to optimum for this crop. ${ }^{5}$

The suckers used for planting were peeled and dipped in an insecticidenematicide solution before planting. These pesticides were later applied in granular form around each plant every 4 months. Fertilizer was applied at the rate of $700 \mathrm{~kg}$ of $10-5-20 /$ ha every 3 months.

The plantains at Gurabo and Corozal were irrigated whenever $50 \%$ of the available moisture in the soil was depleted. At the other locations, rainfall was generally abundant and the plantains were not irrigated.

The root systems were studied about 10 months after planting, just

${ }^{5}$ Irizarry, H., Rivera, E., Rodríguez, J. A., and Green, J. J., 1978. Effect of planting pattern and population density on yield of the horn type Maricongo plantain (Musa acuminata $\times$ M. balbisiana, AAB) in North-Central Puerto Rico, J. Agri. Univ. P.R. 62(3): 214-23. 
before the plantains started to flower. Soil samples $(30 \times 30 \mathrm{~cm}$ and 15 $\mathrm{cm}$ deep) were taken at 0 to 30,30 to 60 and 60 to $90 \mathrm{~cm}$ from the plantain pseudostems, and at the 0 to 15,15 to 30,30 to 45 and 45 to 60 -cm depths on two sides of each of four plants at each location. By hand, the roots were carefully removed from each sample and their lengths determined.

\section{RESULTS AND DISCUSSIONS}

The accompanying figures show the distribution of plantain primary roots at different depths and distances from the plantain pseudostem in
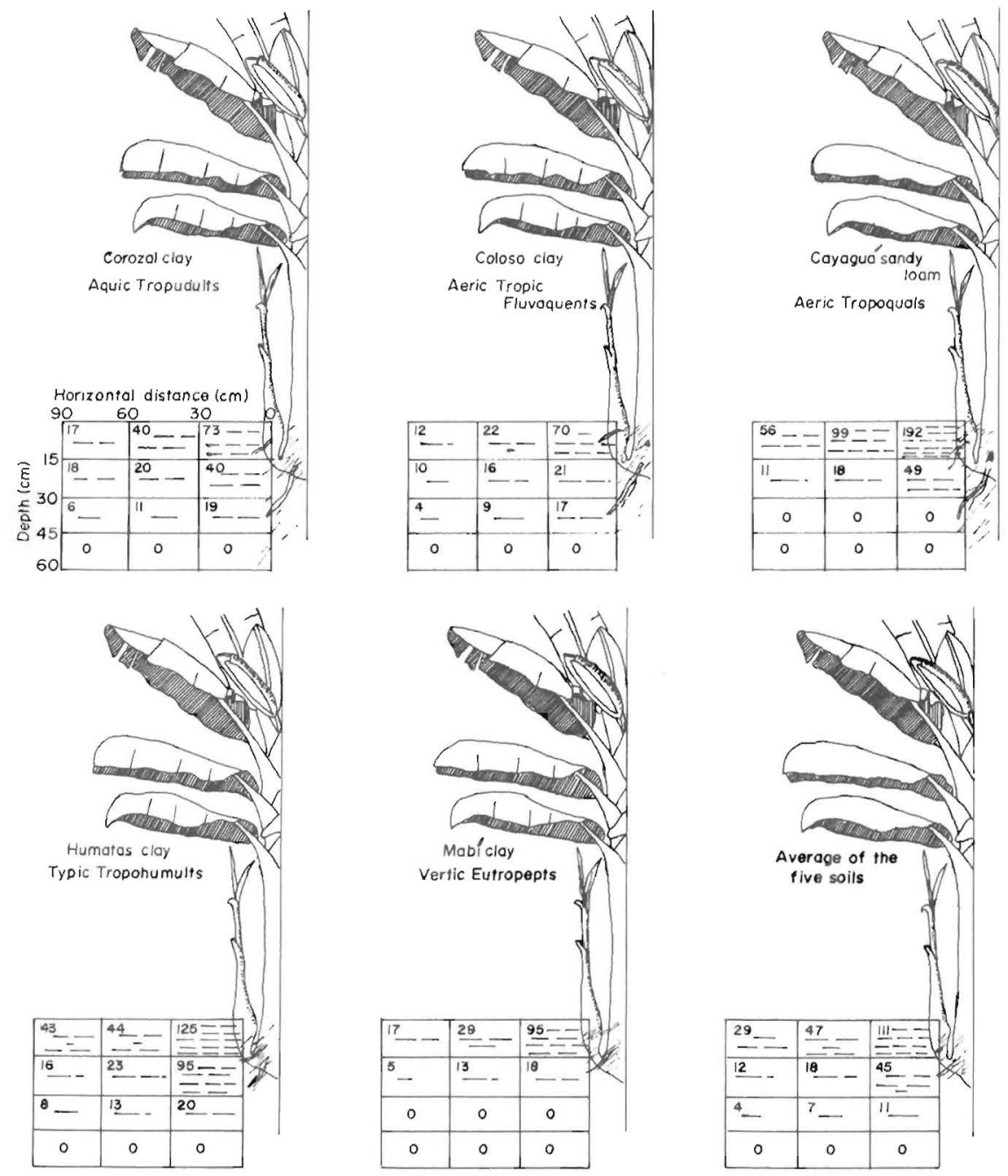

FIG. 1.-Distribution of primary roots of 10 -month-old plantains growing on five soil types typical of large areas in the tropics. Numbers show $\mathrm{cm}$ of roots/1,000 $\mathrm{cm}^{3}$ of soil. 
the different soil types. All values are averages for samples on both sides of each of four plants at each location.

In all soils, and at all depths, plantain roots decreased sharply with distance from the pseudostem (fig. 1). Averages for all soils show that in the upper $15 \mathrm{~cm}$ of soil, the $\mathrm{cm}$ of roots $/ 1,000 \mathrm{~cm}^{3}$ of soil decreased from 111 at 0 to $30 \mathrm{~cm}$ from the pseudostem, to $29 \mathrm{~cm}$ at 60 to $90 \mathrm{~cm}$ from the pseudostem.

In all soils, and at all distances from the pseudostem, plantain roots decreased sharply with depth in the soil. Averages for all soils show that at 0 to $30 \mathrm{~cm}$ from the pseudostem the $\mathrm{cm}$ of roots $/ 1,000 \mathrm{~cm}^{3}$ of soil decreased from 111 at the 0 to $15 \mathrm{~cm}$ depth, to $11 \mathrm{~cm}$ at the $30-$ to $45-\mathrm{cm}$ depth. No plantain roots were found in any soil at depths beyond $45 \mathrm{~cm}$.

The root system of plantains was very extensive in the upper $15 \mathrm{~cm}$ of Cayaguá sandy loam, but there were few roots at the $15-30 \mathrm{~cm}$ depth and none at the relatively impermeable lower depths.

In the Humatas soil, plantain roots were also extensive in the surface layer and were more extensive in the 15 to $30 \mathrm{~cm}$ layer than in any other soil.

The heavier Coloso, Corozal and Mabí soils, contain fewer roots/1,000 $\mathrm{cm}^{3}$ of soil at all depths than did the other soil types.

Due to the rather short and superficial root system of plantains, mechanical cultivation close to the pseudostem should be avoided since this practice would mutilate a large part of the root system.

This peculiar root development in plantains should also be taken into consideration when fertilizers, granular pesticides and irrigation water are applied under field conditions.

\section{RESUMEN}

Se determinó la distribución de las raíces primarias de plataneros unos 10 meses después de sembrados en 5 suelos: Humatas, Corozal, Cayaguá, Mabí y Coloso.

Se tomaron muestras de suelo de $30 \times 30 \mathrm{~cm}$ y $15 \mathrm{~cm}$ de profundidad a 0-30, 30-60 y 60-90 cm del seudotallo y a profundidades de 0-15, 15$30,30-45$ y $45-60 \mathrm{~cm}$ en dos lados opuestos de cada una de cuatro plantas en cada suelo. Las raíces se extranjeron de las muestras a mano y se midieron determinándose el promedio de las 8 muestras tomadas a cada profundidad y distancia del seudotallo en todos los suelos. El largo de las raíces se expresó en cm/1,000 cc de suelo.

En todos los suelos y a todas las profundidades, las raíces disminuyeron marcadamente según aumentaba la distancia del seudotallo. El promedio para todos los suelos a la profundidad de $0-15 \mathrm{~cm}$ fue de 111 $\mathrm{cm}$ de raíces $/ 1,000 \mathrm{cc}$ de suelo a la distancia de $0-30 \mathrm{~cm}$ del seudotallo, pero de sólo $29 \mathrm{~cm}$ de raíces $/ 1,000 \mathrm{cc}$ de suelo a una distancia de 60 $90 \mathrm{~cm}$ del seudotallo. 
En todos los suelos y a todas las distancias del seudotallo, las raíces disminuyeron señalademente con la profundidad en el suelo. El promedio para todos los suelos a una distancia de $0-30 \mathrm{~cm}$ del seudotallo fue de $111 \mathrm{~cm}$ de raíces $/ 1,000 \mathrm{cc}$ de suelo a una profundidad de $0-15 \mathrm{~cm}$ pero de sólo $11 \mathrm{~cm}$ de raíces/1,000 cc de suelo a una profundidad de $30-45 \mathrm{~cm}$. No se encontraron raíces a profundidades mayores de $45 \mathrm{~cm}$ en ninguno de los suelos.

Este sistema radical del platanero deberá tenerse en cuenta cuando los platanales se rieguen, se abonen o se apliquen pesticidas granulados. 